\title{
Prevalence and some risk factors of bovine heamotropic mycoplasma in Nineveh province - Iraq
}

\author{
S.A. Esmaeel ${ }^{1}$ and B.A. Albadrani ${ }^{2}$ \\ Department of Internal and Preventive Medicine, College of Veterinary Medicine, University of Mosul, Mosul, Iraq \\ Email: ${ }^{1}$ salamaljubori96@gmail.com, ${ }^{2}$ basima1971@yahoo.com
}

(Received November 27, 2018; Accepted January 7, 2019)

\begin{abstract}
The objective of current study was to determine the prevalence of bovine heamotropic mycoplasma in cattle using conventional polymerase chain reaction (PCR) in Nineveh province/ Iraq, to investigate some of the epidemiological risk factors associated with occurrence of the disease. From September 2017 - September 2018, four hundred blood samples were obtained from cattle both sexes, different ages, origin, different management systems and from different regions in Nineveh province, ten milliliter blood were collected from the jugular vein for PCR test, whatever epidemiological data were collected through interview with the farms owners. The results of this study appear that the prevalence of bovine heamotropic mycoplasma was $75 \%$. The risk factors associated with increased prevalence of disease include age, increased prevalence was at $>3$ years, females, imported animals, indoor animals which were $86.8,80,91.7,77.5 \%$ respectively. The significantly increased prevalence of the disease $93.7 \%$ in the western regions of Nineveh province. In spring and summer months a significantly increased prevalence of disease which were 79.6 and 78.95 respectively. In conclusions, this study detected that bovine heamotropic mycoplasma was widely distributed in Nineveh province associated with several risk factors.
\end{abstract}

Keywords: Heamotropic mycoplasma, Prevalence, Bovine, Nineveh, Iraq Available online at http://www.vetmedmosul.com

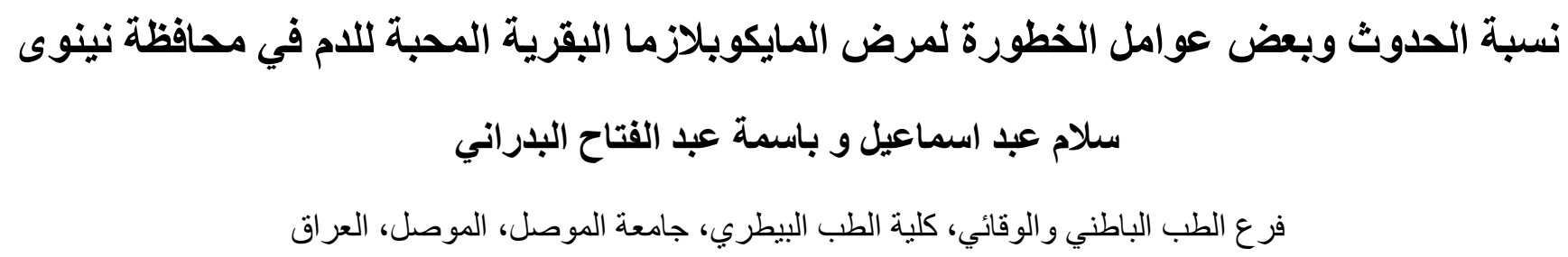

الخلاصة

إن الهدف من الدر اسة الحالية تحديد نسبة انتشار المايكوبلازما البقرية المحبة للام في المانشية باستخدام طريقة تفاعل البلمرة المتسلسل

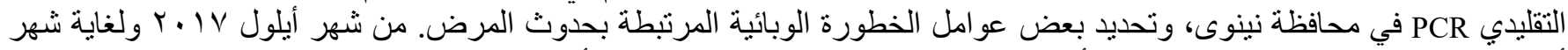

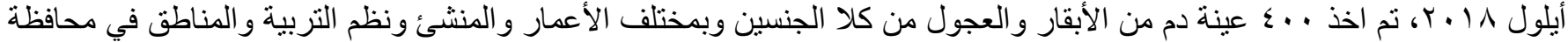

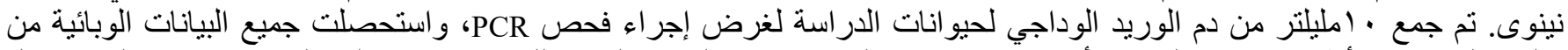

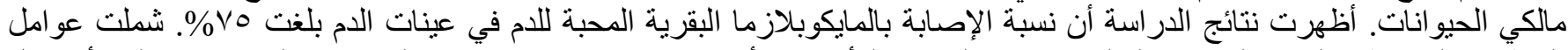

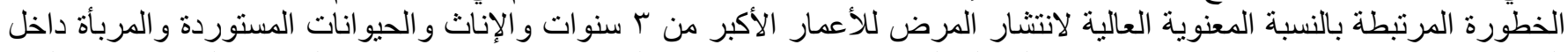

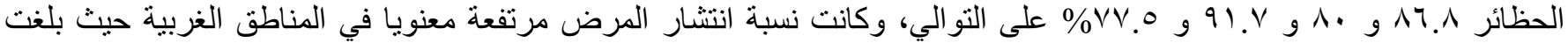

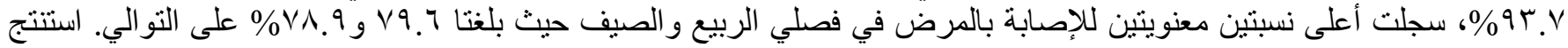
من هذه الدر اسة ان المايكوبلازما البقرية المحبة للام و اسعة الانتشار في محافظة نينوى ومرتبطة بعو الرئن امل خطورة متعددة. 


\section{Introduction}

Heamotropic mycoplasma (heamoplasma) include small, cell wall-free, epierythrocytic bacteria infect the blood of various mammalian $(1,2)$ and consider an emerging bacterial pathogen to a wide variety of animals including livestock, wildlife and companion animals (3-5). Formerly the causative agent classified as Haemobartonella and Eperythrozoon species within the order Rickettsiales, and recently reclassified in the genus Mycoplasma $(1,6-8)$. Bovine Heamotropic mycoplasmas clinically relevant as causative agents of acute, lifethreatening hemolytic anemia in animals. Whatever, few animals may develop only mild clinical signs or be asymptomatic (1). Factors such as gender, age, immune status, or concurrent infection with other pathogenic agents, have been suggested implicated in the development of disease (9-12). Infections caused by Mycoplasma wenyonii and Candidatus Mycoplasma haemobos have been documented in cattle in countries in the Asia-Pacific region, including Japan (13-15), China $(16,17)$ and Europe $(18,19)$. The transmission of hemoplasma is believed to occur through various blood-feeding arthropods, including ticks (20). Due to the lack information about the epidemiology of bovine heamotropic mycoplasma in Mosul/Iraq, this study aimed to determine the prevalence of the disease in cattle and some of the risk factors associated with the disease.

\section{Material and methods}

\section{Animal and Specimens collection}

The epidemiological survey was performed a total of 400 blood samples from cattle (imported, native origin) were collected from jugular vein between September 2017 - September 2018 from both sex, different ages animals (130 days, $<1$ years, 1-3 years, $>3$ years) and different region in Nineveh province (Iraq), The recorded relative risk factors analysis, the blood samples were Immediately placed in EDTA tubes and stores at $-20^{\circ} \mathrm{C}$ prior to DNA extraction.

\section{Polymerase chain reaction technique}

A total genomic DNA was extracted from 300 micro litter blood samples with a commercially available kit (blood samples Bioingentech veterinary extraction, purification kit, Chile) and stores $-20^{\circ} \mathrm{C}$ until PCR testing.

PCR was carried out using primers Mycoplasma genus - specific primers: specific primers for the 16S rRNA gene of bovine heamotropic mycoplasma, forward primer: 5'ATATTCCTACGGGAAGCAGC-3', equivalent to nucleotide numbers 328 to 347 of $M$. wenyonii, reverse primer :5'-ACCGCAGCTGCTGGCACATA-3', equivalent to nucleotide numbers 503 to 522 of $M$. wenyonii amplified a 195 base pair and 173 base pair product for $M$. wenyonii and 'Candidatus M. haemobos', respectively (21) with few modification. With final volume 20 microliter PCR reaction consist of 2 microliter of DNA samples, 1 microliter forward primer (10 Pico mole) and 1 microliter reverse primer (10 Pico mole), 4 microliters of $5 \times$ Taq master mix, 12 microliter PCR Grade water. The PCR program included initial denaturation at $94^{\circ} \mathrm{C}$ for $30 \mathrm{sec}$. Denaturation $94{ }^{\circ} \mathrm{C}$ for 30 sec. 31 cycles, Anneling $57^{\circ} \mathrm{C} 30$ second, extension $72{ }^{\circ} \mathrm{C}$ for 1 minute and final extension $72{ }^{\circ} \mathrm{C}$ for $2 \mathrm{~min}$., cooling $4{ }^{\circ} \mathrm{C}$. The electrophorese run on $1.5 \%$ gel agarose and visualized using UV imager.

\section{Statistical analysis}

The Statistical analysis was done by using computed 2 by 2 tables in Epi-InfoTM 7 software (version 7).

\section{Results}

In the present study overall prevalence of bovine heamotropic mycoplasma in Nineveh Province was 75\% (300 out of 400) by conventional polymerase chain reaction (Figure1).

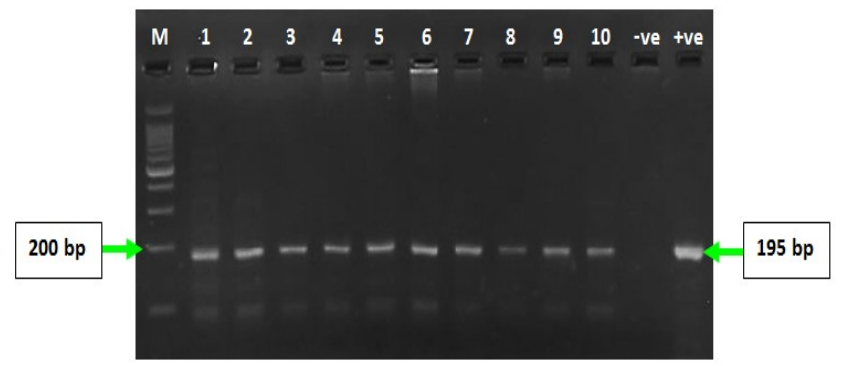

Figure 1: PCR 16S rRNA Gene for bovine heamotropic mycoplasma (195bp) on agarose gel the, lane 1-10 positive blood sample, -ve lane negative sample, +ve lane positive control.

This study revealed that the Prevalence of the disease was significantly increased in cattle aged more than $>3$ years RR: 1.98 times, CI: 1.13 - 3.44 Compare to other ages (Table 1). The current study appears that the prevalence was significantly increased in female compared to male cattle $(\mathrm{P}<0.0001) \mathrm{RR}$ : 1.20 times, $\mathrm{CI}$ : $1.05-1.36$. The prevalence was also significantly increased among imported cattle (RR: 1.33 times, CI: 1.212 - 1.46) compared to native cattle $(\mathrm{P}<0.0001)$ (Table 1$)$. Also, the study indicated that the prevalence of the disease was significantly higher in indoor feeding $77.5 \%$ in compared to outdoor feeding $66.6 \%(\mathrm{P}<0.034) \mathrm{RR}$ : 1.11 times, $\mathrm{CI}$ : 0.99 - 1.35 (Table1). Based on regional factors the west, south and east regions of the city showed significantly 
increased prevalence of the disease $(\mathrm{P}<0.003)$ (RR: 7.47 times, CI: 1.35-2.25) compared to the city center and north regions (Table 2).This study also demonstrated that the prevalence was significantly increased in spring and summer seasons, 79.6 and $78.7 \%$ respectively (RR: 1.31 and 1.30 times respectively) compared to the winter and autumn seasons (Table 3).

Table1: Relative risk factors of cattle associated with the prevalence rate of the Haemotropic mycoplasma

\begin{tabular}{|c|c|c|c|c|c|}
\hline \multirow{2}{*}{ Factors } & \multirow{2}{*}{ No. tested cattle } & \multicolumn{4}{|c|}{ PCR technique } \\
\hline & & No of positive (\%) & RR & $95 \% \mathrm{CI}$ & $\mathrm{P}$ \\
\hline \multicolumn{6}{|l|}{ Age } \\
\hline $1-30$ days & 16 & $7(43.7 \%)^{\mathrm{a}}$ & 1 & & \\
\hline$<1$ years & 107 & $73(68.2 \%)^{b}$ & 1.55 & $0.88-2.75$ & 0.05 \\
\hline 1-3years & 125 & $88(70.4 \%)^{b}$ & 1.60 & $0.9-2.83$ & 0.032 \\
\hline$>3$ years & 152 & $132(86.8 \%)^{\mathrm{c}}$ & 1.98 & $1.13-3.47$ & 0.0001 \\
\hline \multicolumn{6}{|l|}{ Gender } \\
\hline Male & 150 & $100(66.6 \%)^{\mathrm{a}}$ & 1 & & \\
\hline Female & 250 & $200(80 \%)^{b}$ & 1.20 & $1.05-1.36$ & 0.002 \\
\hline \multicolumn{6}{|l|}{ Origin } \\
\hline Native & 291 & $200(8.7 \%)^{\mathrm{a}}$ & 1 & & \\
\hline Imported & 109 & $100(91.7 \%)^{\mathrm{b}}$ & 1.33 & $1.212-1.469$ & 0.0001 \\
\hline \multicolumn{6}{|l|}{ Husbandry system } \\
\hline Outdoor feeding & 93 & $62(66.6 \%)^{\mathrm{a}}$ & 1 & & \\
\hline Indoor feeding & 307 & $238(77.55 \%)^{\mathrm{b}}$ & 1.11 & $0.99-1.35$ & 0.034 \\
\hline
\end{tabular}

Values significantly different $(\mathrm{P}<0.05)$ labeled with different letters $(\mathrm{a}, \mathrm{b}$ or $\mathrm{c})$.

Table 2: Relative risk of regional factors associated with the prevalence rate of the Haemotropic mycoplasma

\begin{tabular}{lccccc}
\hline \multirow{2}{*}{ Regional factors } & \multirow{2}{*}{ No. tested cattle } & \multicolumn{4}{c}{ PCR technique } \\
\cline { 3 - 6 } & & No. positive $(\%)$ & RR & $95 \%$ CI & P \\
\hline North regions & 67 & $36(53.7 \%)^{\mathrm{a}}$ & 1 & & 0.09 \\
City center & 93 & $62(66.6 \%)^{\mathrm{a}}$ & 0.71 & $0.95-1.6$ & 0.0001 \\
East regions & 212 & $176(83 \%)^{\mathrm{b}}$ & 0.44 & $1.22-1.94$ & 0.01 \\
South regions & 12 & $11(91.6 \%)^{\mathrm{b}}$ & 0.21 & $1.28-2.25$ & 0.003 \\
West regions & 16 & $15(93.7 \%)^{\mathrm{b}}$ & 7.47 & $1.35-2.25$ & \\
\hline
\end{tabular}

Values significantly different $(\mathrm{P}<0.05)$ are labeled with different letters $(\mathrm{a}, \mathrm{b}$ or $\mathrm{c})$.

Table 3: Relative risk of seasonal factors associated with the prevalence rate of the Haemotropic mycoplasma

\begin{tabular}{lccccc}
\hline \multirow{2}{*}{ Factors } & \multirow{2}{*}{ No. cattle tested } & \multicolumn{4}{c}{ PCR test } \\
\cline { 3 - 6 } & & No. positive $(\%)$ & RR & $95 \%$ CI & P \\
\hline Autumn 2017 & 56 & $34(60.7 \%)^{\mathrm{a}}$ & 1 & \\
Winter 2017 & 52 & $34(65.3 \%)^{\mathrm{a}}$ & 1.07 & $0.80-1.43$ & 0.61 \\
Summer 2017 & 76 & $60(78.9 \%)^{\mathrm{b}}$ & 1.30 & $1.02-1.65$ & 0.02 \\
Spring 2017 & 216 & $172(79.6 \%)^{\mathrm{b}}$ & 1.31 & $1.05-1.63$ & 0.003 \\
\hline
\end{tabular}

Values significantly different $(\mathrm{P}<0.05)$ are labeled with different letters $(\mathrm{a}, \mathrm{b}, \mathrm{c})$.

\section{Discussion}

Heamotropic mycoplasma is of great economic importance in relation to the infectious agents affecting cattle $(20,22)$. This is the first epidemiological study of disease in Nineveh province. The study shows overall of the prevalence rate of disease in Mosul was $75 \%$. Lower and/or near similar prevalence has been reported in earlier studies of the disease in Iraq and other countries, the prevalence was $83.3 \%$ in cattle by using PCR in Basrah (23). In China $21.5 \%$ (17), In Japan 38.5\% (24), in Malaysia 50\% (25), In Ghana 32\% (26), In Brazil 60.9\% (27) and In Switzerland $85 \%$ (28). The prevalence of the disease may differ from country to other and even within 
regions of the same country and this might due to the different in management practices, number of samples, sensitivity of the diagnostic methods, incidence of competent vectors, efficacy of control programs, climatic variations, extensive cattle trade, uncontrolled animal movement, population size and biosecurity $(3,14)$.

The current study revealed a considerable difference in the prevalence of disease among the age range of cattle, higher prevalence rate was revealed in cattle more than $>3$ years, which may be due to stress factors or concurrent infection and Immune States. This finding was consistent with $(25,29,30)$.

The current study appears increased prevalence of disease in female which agreed with (25) and may be due to stress factors such as lactation, pregnancy, immunosuppression. The result revealed that the prevalence was significantly higher among imported cattle than native cattle, due possibly to the fact that most of the cattle population in Nineveh province are imported from Iran, Turkey and Syria in which the disease is prevalent $(31,32,33)$. It should also be noted that some of the imported cattle were often brought into Nineveh province without border control and quarantine.

The result also revealed that the prevalence significantly higher among indoor feeding cattle in compared to outdoor feeding cattle, due possibly to overcrowding cattle in stockyard and present of ticks, this result agreed with (24). According to the geographical regions this study demonstrated that the prevalence of disease was significantly higher in west, south and east regions compared to with city center and north regions. This difference could partly be explained by factors such as high cattle population density, close distances between animals, poor management, animal movements or livestock trade, large animal markets, meeting between the owners and attenders, climatic factors.

This study demonstrated that the prevalence was significantly higher in spring and summer seasons in compared to autumn and winter season. This finding was similar to the results mentioned by (34). The causations may be relevancy with climate which related with tick's reproduction in these seasons.

\section{Acknowledgement}

This article was supported by the College of Veterinary Medicine, University of Mosul, Iraq.

\section{References}

1. Messick JB. New perspectives about hemotrophic mycoplasma (formerly, Haemobartonella and Eperythrozoon species) infections in dogs and cats. Vet Clin N Am Small Anim Pract. 2003;33:14531465.DOI:10.1016/j.cvsm.2003.08.002
2. Sharifiyazdi H, Abbas $\mathrm{ZH}$, Amini AH. Intravascular hemolysis associated with Candidatus Mycoplasma hematoparvum in a nonsplenectomized dog in the south region of Iran. Vet Res Forum. 2014;5:243-246. PMID:25568726 ,PMCID:PMC4279639.

3. Fujihara Y, Sasaoka F, Suzuki J, Watanabe Y, Fujihara M, Ooshita $\mathrm{K}$, Ano H, Harasawa R. Prevalence of hemoplasma infection among cattle in the western part of Japan. J Vet Med Sci. 2011;73:16531655. doi: 10.1292/jvms.11-0269.

4. Maggi RG, Compton SM, Trull CL, Mascarelli PE, Mozayeni BR, Breitschwerdt EB. Infection with hemotropic Mycoplasma species in patients with or without extensive arthropod or animal contact. J Clin Microbiol. 2013;51:3237-3241. doi: 10.1128/JCM.01125-13.

5. Watanabe Y, Fujihara M, Obara H,Matsubara K, Yamauchi K, Harasawa R. Novel hemoplasma species detected in free-ranging sika deer (Cervusnippon). J Vet Med Sci. 2010;72:1527-1530. DOI:10.1292/jvms.10-0229.

6. Neimark HKE, Johansson Y, Rikihisa J, Tully G. Revision of haemotrophic Mycoplasma species names. Int J Syst Evol Microbiol. 2002;52:683. DOI10.1099/00207713-52-2-683.

7. Rikihisa YM, Kawahara B, Wen G, Kociba P, Fuerst F, Kawamori C, Suto S, Shibata M, Futohashi A. Western immunoblot analysis of Haemobartonella muris and comparison of 16S rRNA gene sequences of H. muris, H. felis, and Eperythrozoon suis. J Clin Microbiol. 1997;35:823-829. DOI: 0095-1137/00/\$04.0010.

8. Tasker SC, Helps R, Belford CJ, Birtles RJ, Day MJ, Sparkes AH, Gruffydd TJ, Harbour DA. 16S rDNA comparison demonstrates near identity between a United Kingdom Haemobartonella felis strain and the American California strain. Vet Microbiol. 2001;81:73-78. doi.org/10.1016/S0378-1135(01)00331-5.

9. Grindem CB, Corbett WT, Tomkins MT. Risk factors for Haemobartonella felis infection in cats. J Am Vet Med Assoc. 1990;196:96-99. PMID:2295559.

10. Tagawa M, Ybaez AP, Matsumoto K, Yokoyama N, Inokuma H. Prevalence and risk factor analysis of bovine hemoplasma infection by direct PCR in Eastern Hokkaido, Japan. J Vet Med Sci. 2012;74:1171-1176. doi: 10.1292/jvms.12-0118.

11. Tasker SS, Binns H, Day MJ, Gruffydd TJ, Harbour DA, Helps CR, Jensen WA, Olver CS, Lappin MR. Use of a PCR assay to assess the prevalence and risk factors for Mycoplasma haemofelis and 'Candidatus Mycoplasma haemominutum' in cats in the United Kingdom. Vet Rec. 2003;152:193-198. DOI: 10.1128/JCM.41.1.439441.2003.

12. Willi BFS, Boretti C, Baumgartner S, Tasker B, Wenger V, Cattori ML, Meli CE, Reusch H, Lutz R, Hofmann L. Prevalence, risk factor analysis, and follow-up of infections caused by three feline hemoplasma species in cats in Switzerland. J Clin Microbiol. 2006;44:961-969. DOI: 10.1128/JCM.44.3.961-969.2006

13. Tagawa M, Matsumoto K, Inokuma H. Molecular detection of Mycoplasma wenyonii and 'Candidatus Mycoplasma haemobos' in cattle in Hokkaido, Japan. Vet Microbiol. 2008;132:177-180. doi: $10.1016 /$ j.vetmic. 2008

14. Tagawa M, Matsumoto K, Yokoyama N, Inokuma H. Comparison of the effect of two hemoplasma species on hematological parameters in cattle. J Vet Med Sci. 2010;72:113-115. doi: 10.1292/jvms.09-0304

15. Tagawa M, Yamakawa K, Aoki T, Matsumoto K, Ishii M, Inokuma H. Effect of chronic hemoplasma infection on cattle productivity. J Vet Med Sci. 2013;75:1271-1275. doi: 10.1292/jvms.13-0119.

16. Congli Y, Hong Y, Zhonghai Z, Zhibiao Y, Li C, Jianguo Z, Xiuguo $\mathrm{H}$. Prevalence of Mycoplasma wenyonii infection on seven dairy 
farms in Shanghai, China. Thai J Vet Med. 2011;41:6. https://www.tci-thaijo.org/index.php/tjvm/article/view/9526.

17. Song Q, Wang L, Fang R, Khan MK, Zhou Y, Zhao J. Detection of Mycoplasma wenyonii in cattle and transmission vectors by the loopmediated isothermal amplification (LAMP) assay. Trop Anim Heal Prod. 2013;45:47-250. doi: 10.1007/s11250-012-0197-y.

18. Hoelzle K, Winkler M, Kramer MM, Wittenbrink MM, Dieckmann SM, Hoelzle LE. Detection of Candidatus Mycoplasma haemobos in cattle with anaemia. Vet J. 2011;187:408-410. doi: 10.1016/j.tvj1.2010.01.016.

19. Hofmann-Lehmann R, Meli ML, Dreher UM, Gonczi E, Deplazes P, Braun U, Engels M, Schupbach J, Jorger K, Thoma R, Griot C, Stark KD, Willi B, Schmidt J, Kocan KM, Lutz H. Concurrent infections with vectorborne pathogens associated with fatal hemolytic anemia in a cattle herd in Switzerland. J Clin Microbiol. 2004;42:775-3780. doi: 10.1128/JCM.42.8.3775-3780.2004.

20. Neimark H, Johansson KE, Rikihisa Y, Tully JG. Proposal to transfer some members of the genera Haemobartonella and Eperythrozoon to the genus Mycoplasma with descriptions of 'Candidatus Mycoplasma haemofelis', 'Candidatus Mycoplasma haemomuris', 'Candidatus Mycoplasma haemosuis' and 'Candidatus Mycoplasma wenyonii'. Int J Syst Evol Microbiol. 2001;51:891-899. doi: 10.1099/00207713-51-3-891.

21. Nishizawa I, Sato M, Fujihara M, Sato S, Harasawa R. Differential detection of hemotropic Mycoplasma species in cattle by melting curve analysis of PCR products. Vet Med Sci. 2010;72:77-79. DOI:10.1292/jvms.09-0338.

22. Messick JB. Hemotrophic mycoplasmas (hemoplasmas): a review and new insights into pathogenic potential. Vet Clin Pathol. 2004;33:2-13. DOI: 10.1111/j.1939-165X.2004.tb00342.x.

23. Jarad A, Alsaad KM. Clinical, Hematological and Diagnostic studies of Mycoplasma wenyonii infection in cattle of Basrah Governorate Basrah, Iraq. Bas J Vet Res. 2016;15(4):37-53.

24. Tagawa M, Ybaez AP, Matsumoto K, Yokoyama N, Inokuma H. Prevalence and risk factor analysis of bovine hemoplasma infection by direct PCR in Eastern Hokkaido, Japan. J Vet Med Sci. 2012;74:1171-1176. doi: 10.1292/jvms.12-0118.

25. Hasan LI, Kho KL, Koh FX, Hassan QN, Tay ST. Molecular evidence of hemoplasmas in Malaysian cattle and ticks. Trop
Biomed. 2017; 34(3): 668-674. doi.org/10.1016/S0378$1135(02) 00298-5$.

26. Sakyia B, Koneya EBM, Dogbeya O, Walkerb AR. Incidence and prevalence of tick-borne haemoparasites in domestic ruminants in Ghana. Vet Parasitol. 2004;124:25-42. DOI:10.1016/j.vetpar.2004.05.027.

27. Girotto A, Zangirolamo AF, Bogado AL, Souza AS, Silva GC, Garcia JL, Vilas Boas LA, Biondo AW, Vidotto O. Molecular detection and occurrence of 'Candidatus Mycoplasma haemobos' in dairy cattle of Southern Brazil. Braz J Vet Parasitol. 2012;21:342344. http://dx.doi.org/10.1590/S1984-296120120003000.

28. Meli ML, Willi B, Dreher UM, Cattori V, Knubben-Schweizer G, Nuss K. Identification, molecular characterization, and occurrence of two bovine hemoplasma species in Swiss cattle and development of real-time TaqMan quantitative PCR assays for diagnosis of bovine hemoplasma infections. J Clin Microbiol. 2010;48(10):3563-3568. doi: 10.1128/JCM.02224-09.

29. Yuan CYH, Zhang Z, Yang Z, Cui L, Zhu J, Hua X. Prevalence of Mycoplasma wenyonii Infection on Seven Dairy Farms in Shanghai, China. Thai J Vet Med. 2011;41(2):179-184.

30. Sasaoka F, Jin S, Toh H, Toshihiro I, Kazuhisa F, Ryô H, Hiroshi S. Vertical transmission of Mycoplasma wenyonii in cattle, supported by analysis of the ribonuclease $\mathrm{p}$ rna gene - short communication. Acta Veterinaria Hungarica. 2015;63(3):271-274. doi: 10.1556/004.2015.025.

31. Al-Khalifa MS, Khalil GM, Hussein HS, Diab FM. A preliminary study on the effect of a concurrent infection with Eperythrozoon wenyonii on the development of Theileria annulata in calves. Saudi J Biol Sci. 2008;15:73-79.

32. Nazifi S, Oryan A, Bahrami SM. Evaluation of haematological and serum biochemical parameters in Iranian camels infected with haemotrophic (eperythrozoon) Spp. Comp Clin Pathol. 2009;18(3):329-332. https://doi.org/10.1007/s00580-008-0807.

33. Saki CS, Ozer E. Clinical Eperythrozoon wenyonii (Adler and Ellenboger, 1934) and Haemobartonella bovis (Donatin and Lostoquard,1934) infection in a cattle. Fir Uni Sag Bili Vet Der. 2009;23(2):117-118.

34. Novacco M, Meli ML, Gentilini F. Prevalence and geographical distribution of canine hemotropic mycoplasma infections in Mediterranean countries and analysis of risk factors for infection. Vet Microbiol. 2010;142(3):276-284. DOI:10.1016/j.vetmic.2009.09.069 